\title{
Level Tapioka dan Lama Fermentasi terhadap Kandungan Nutrien Silase Kulit Pisang Kepok
}

\section{Difference of Tapioca Levels and Duration of Fermentation to Nutrient Content of Kepok Banana Peel Silage}

\author{
T. N. I. Koni ${ }^{1 *}$, T. A. Y. Foenay ${ }^{1}$, dan H. Y. Chrysostomus ${ }^{2}$ \\ ${ }^{1}$ Jurusan Peternakan, Politeknik Pertanian Negeri Kupang, Kupang 85011, NTT - Indonesia \\ ${ }^{2}$ Fakultas Peternakan, Universitas Papua, Manokwari Papua Barat 98314 - Indonesia \\ *Corresponding E-mail: theresia.koni@staff.politanikoe.ac.id \\ (Diterima: 17 September 2020; Disetujui: 24 Februari 2021)
}

\begin{abstract}
ABSTRAK
Serat kasar yang tinggi pada kulit pisang merupakan salah satu pembatas penggunaannya sebagai pakan ternak monogastrik. Fermentasi, seperti yang digunakan dalam produksi silase, menurunkan kadar serat kasar. Tapioka dan karbohidrat larut lainnya dibutuhkan untuk membuat silase. Tujuan dari penelitian ini adalah untuk mengkaji pengaruh penggunaan tepung tapioka dan lama fermentasi terhadap komposisi nutrien silase kulit pisang. Terdapat 12 kombinasi perlakuan dalam penelitian ini, menggunakan Rancangan Acak Lengkap pola faktorial ( $3 \times 4)$, dua faktor yaitu jumlah tepung tapioka $(5,10,15 \%)$ dan lama fermentasi $(7,14,21$, dan 28 hari). Tiga ulangan dari setiap perlakuan. Parameter penelitian adalah bahan kering, protein kasar, serat kasar, lemak kasar, dan abu. Hasil penelitian menunjukkan bahwa interaksi kadar tapioka dan lama fermentasi mempengaruhi kadar bahan kering, protein kasar, serat kasar, lemak kasar, dan abu silase pada kulit pisang. Pada perlakuan tapioka 15\% dan lama fermentasi 28 hari, silase kulit pisang kepok memiliki kadar serat kasar paling rendah.
\end{abstract}

Kata kunci: tapioka, lama fermentasi, kandungan nutrien, silase, kulit pisang kepok

\section{ABSTRACT}

The high crude fiber of banana peels causes the limitations of its use as monogastric animal feedstuff. Fermentation, as used in silage production, decreases the crude fiber content. Tapioca and other soluble carbohydrates are needed to make silage. This study aimed to know how tapioca flour and fermentation time affected the nutrient content of banana peel silage. There were 12 treatment combinations in this study, using a completely randomized design with a factorial pattern ( $3 \times 4)$, two factors, namely the amount of tapioca flour $(5,10,15 \%)$ and the length of fermentation $(7,14,21$, and 28 days) - three replications of each treatment. Dry matter, crude protein, crude fiber, crude fat, and ash were the Study's parameters. The results showed that the interaction of tapioca levels and fermentation time affected the levels of dry matter, crude protein, crude fiber, crude fat, and silage ash in banana peels. At $15 \%$ tapioca treatment and 28 days of fermentation time, Kepok banana peel silage had the lowest crude fiber content.

Keywords: tapioca, duration of fermentation, nutrient content, silage, Kepok banana peel

\section{PENDAHULUAN}

Pakan ternak dapat dibuat dari limbah pengolahan makanan seperti kulit pisang. Kulit pisang menyumbang 25 sampai $40 \%$ dari total berat buah pisang (Koni, 2013;
Wadhwa et al., 2015). Situmorang (2020) menyatakan bahwa nutrien yang terkandung pada kulit pisang seperti $6,38 \%$ protein kasar, $8,33 \%$ lemak kasar, $15,25 \%$ serat kasar dan. $2885 \mathrm{kcal} / \mathrm{kg}$ energi metabolik. Selain itu kulit pisang juga mengandung mineral 2,52-5,17\%, 
kalsium $0,36-7,18 \%$, fosfor (Widjastuti dan Hernawan, 2012; Koni, 2013; Fitroh et al., 2018). Koni et al. (2013) dan Widjastuti dan Hernawan (2012) menyatakan bahwa sebagai pakan ayam broiler, kulit kepok dapat dimanfaatkan hingga $7,5 \%$, sedangkan kulit pisang terfermentasi dengan Rhizopus oligosporus dapat dimanfaatkan hingga $10 \%$.

Rendahnya penggunaan kulit pisang dalam pakan ternak non ruminansia disebabkan karena tingginya kadar serat kasar pada kulit pisang tersebut. Serat kasar dapat diturunkan menggunakan teknologi fermentasi. Setelah kulit pisang diolah menjadi silase Koni dan Foenay (2019) menemukan bahwa kadar serat kasar menurun $22,19-43,41 \%$ dan kadar protein meningkat 82,09 - 166,11\%. Karbohidarat mudah larut merupakan aditif dalam pembuatan silase, yang dimanfaatkan oleh mikroorganisme sebagai sumber energi sehingga bakteri penghasil enzim selulase dapat bekerja secara optimum sehingga bahan organik meningkat (Utomo et al., 2016; Santi et al., 2012). Koni dan Foenay (2020) menyatakan bahwa tapioka merupakan karbohidrat terbaik yang mampu menurunkan kadar serat kasar tertinggi pada silase kulit pisang.

Kualitas silase dipengaruhi oleh jenis karbohidrat mudah larut yang digunakan dan lama inkubasi yang diterapkan. Atika et al. (2015) menyatakan bahwa kadar serat kasar pada limbah sayuran dipengaruhi oleh jumlah penambahan tepung gaplek. Menurut Utomo et al. (2013) bahwa jumlah onggok yang ditambahkan dan lama fermentasi mempengaruhi kualitas silase isi rumen. Jika dalam pembuatan silase ditambahkan tepung tapioka maka kualitas silase meningkat. Kandungan nutrien silase yang dihasilkan dipengaruhi oleh jumlah tepung tapioka yang ditambahkan dan lama fermentasi. Karena itu penelitian ini dilakukan agar diketahui level tapioka terbaik dan lama fermentasi yang optimum yang menghasilkan nutrien terbaik pada silase kulit pisang.

\section{METODE}

\section{Materi Penelitian}

Materi yang digunakan yaitu limbah pengolahan pisang (pembuatan gorengan) berupa kulit pisang kepok yang ada di sekitar Kota Kupang, tepung tapioka sebagai karbohidrat mudah larut, timbangan digital Camry dengan kapasitas $5000 \mathrm{~g}$ dan kepekaan $1 \mathrm{~g}$, untuk menimbang materi penelitian, stoples plastik kapasitas 1 liter sebanyak 36 buah.

\section{Prosedur Penelitian}

Silase kulit pisang dibuat sesuai petunjuk Koni dan Foenay (2019) yaitu: pengumpulan kulit pisang yang diambil dari penjual gorengan. Dalam penelitian ini menggunakan pisang matang ditandai warna kulit kuning berwarna. Untuk mengeluarkan kotoran yang melekat maka kulit pisang dicuci, kemudian ditiriskan dan dilanjutkan dengan pemotongan $\pm 3 \mathrm{~cm}$. Kulit pisang ditimbang sebanyak 850 gram untuk setiap unit percobaan, ini merupakan hasil penimbangan setelah dilakukan pemadatan pada toples yang digunakan dan dijadikan patokan untuk berat kulit pisang pada setiap perlakuannya. Tapioka digunakan 5, 10, dan $15 \%$ dari berat kulit pisang. kemudian kulit pisang dicampur dengan tapioka sesuai perlakuan hingga homogen. Campuran kulit pisang dan tapioka dimasukan ke dalam toples plastik sambil dipadatkan. Setelah padat ditutupi plastik bening kemudian toples ditutup dan bagian luar tutupan toples diberi flak ban, agar benar-benar kedap udara. Kulit pisang difermentasi pada suhu ruang selama waktu sesuai perlakuan yaitu 7, 14, 21 dan 28 hari. Penimbangan, silo ditimbang setiap dua hari hingga waktu fermentasi yang ditentukan. Pengeringan, setelah dilakukan penilain fisik hasil silase dikeringkan dalam oven $60^{\circ} \mathrm{C}$ selama 48 jam hingga kering. Kemudian silase dihaluskan dan kemudian dilakukan analisis proksimat untuk mengetahui kandungan nutriennya. 
Tabel 1. Kadar bahan kering silase kulit pisang yang difermentasi menggunakan aras tapioka dan waktu fermentasi yang berbeda

\begin{tabular}{|c|c|c|c|c|c|}
\hline \multirow{2}{*}{$\begin{array}{c}\text { Level Tapioka } \\
(\%)\end{array}$} & \multicolumn{4}{|c|}{ Lama Waktu Fermentasi (hari) } & \multirow{2}{*}{ Rataan $\pm \mathrm{SD}$} \\
\hline & 7 & 14 & 21 & 28 & \\
\hline 5 & $62,77 \pm 2,19 \mathrm{~g}$ & $68,05 \pm 0,65^{\mathrm{e}}$ & $63,32 \pm 1,43^{\mathrm{f}}$ & $59,79 \pm 1,59^{\mathrm{h}}$ & $63,48 \pm 3,37$ \\
\hline 10 & $69,45 \pm 1,14^{\mathrm{e}}$ & $71,48 \pm 0,13^{\mathrm{d}}$ & $64,20 \pm 0,65^{\mathrm{f}}$ & $53,66 \pm 2,26^{\mathrm{i}}$ & $64,70 \pm 7,48$ \\
\hline 15 & $74,89 \pm 0,48^{\mathrm{b}}$ & $75,88 \pm 0,30^{\mathrm{b}}$ & $81,66 \pm 2,76^{\mathrm{a}}$ & $73,72 \pm 1,28^{\mathrm{c}}$ & $71,54 \pm 6,15$ \\
\hline Rataan & $69,04 \pm 5,41$ & $71,80 \pm 3,42$ & $67,08 \pm 5,44$ & $53,37 \pm 4,12$ & \\
\hline
\end{tabular}

Keterangan: Superskrip yang berbeda pada baris dan kolom yang sama menunjukkan perbedaan nyata $(\mathrm{P}<0,05) ; \mathrm{SD}=$ Simpangan baku.

\section{Rancangan Penelitian}

Terdapat 12 kombinasi perlakuan, yang menggunakan rancangan acak lengkap dengan pola faktorial ( $3 \times$ x 4 ), dua faktor yaitu jumlah tepung tapioka $(5,10,15 \%)$ dan lama fermentasi $(7,14,21$, dan 28 hari). Tiga ulangan untuk setiap unit percobaan.

\section{Parameter Penelitian}

Parameter penelitian yaitu bahan kering, protein kasar, serat kasar, lemak kasar, abu diukur sesuai metode AOAC (2005).

\section{Analisis Data}

Data kandungan nutrien silase kulit pisang dianalisis menggunakan analisis varians pola faktorial dan bila terdapat perbedaan dilanjutkan dengan Duncan's Multiple Range Test (DMRT) (Gasperz, 2006).

\section{HASIL DAN PEMBAHASAN}

\section{Kadar Bahan Kering Silase Kulit Pisang}

Kandungan bahan kering pada silase kulit pisang kepok berkisar 53,66 hingga $81,66 \%$ (Tabel 1). Analisis sidik ragam menunjukkan bahwa kadar bahan kering silase kulit pisang secara nyata $(\mathrm{P}<0,05)$ dipengaruhi oleh interaksi aras tapioka dan waktu fermentasi. Perlakuan tapioka 15\% menghasilkan kadar bahan kering 81,66\% setelah dilakukan fermentasi selama 21 hari. Hal ini disebabkan karena kontribusi kadar bahan kering tepung tapioka yang semakin tinggi. Hasil penelitian ini sejalan dengan penelitian Utomo et al. (2013) bahwa peningkatan kadar onggok hingga $30 \%$ menyebabkan terjadi peningkatan kadar bahan kering pada silase isi rumen. Peningkatan waktu fermentasi hingga 14 hari meningkatkan kandungan bahan kering silase kulit pisang, namun menurun pada waktu fermentasi 21 dan 28 hari. Hal ini disebabkan karena makin panjang waktu fermentasi maka makin banyak peluang bagi mikroorganisme untuk bertumbuh sehingga makin tinggi pula metabolisme mikroorganisme yang dihasilkan, dan pada proses tersebut adanya pelepasan $\mathrm{H}_{2} \mathrm{O}$ sehingga mempertinggi kadar air dan menurunkan kadar bahan kering. Olagunju and Ifesan (2013) menyatakan bahwa peningkatan kadar air pada produk fermentasi disebabkan karena dalam proses metabolism mikroorganisme menghasilkan $\mathrm{H}_{2} \mathrm{O}$ (air), sehingga menambah kadar air dan mengurangi kadar bahan kering dari bahan yang difermentasi.

\section{Kadar Protein Kasar Silase Kulit Pisang}

Silase kulit pisang pada penelitian ini mempunyai kandungan protein kasar rata-rata 4,73\% (Tabel 2). Kadar protein kasar pada kulit pisang yang dikeringkan sebesar 3,63\% (Koni et al., 2013) lebih rendah daripada hasil penelitian ini. Mendoza et al. (1994) menyatakan bahwa protein mikroorganisme yang terbentuk pada proses fermentasi menyumbangkan peningkatan kadar protein pada substrat.

Kombinasi level tapioka dan lama 
Tabel 2. Kadar protein kasar (\%) silase kulit pisang yang difermentasi menggunakan aras tapioka dan waktu fermentasi yang berbeda

\begin{tabular}{cccccc}
\hline \multirow{2}{*}{$\begin{array}{c}\text { Level Tapioka } \\
(\%)\end{array}$} & 7 & 14 & 21 & 28 & Rataan \pm SD \\
\cline { 2 - 5 } & $6,70 \pm 0,25^{\mathrm{ab}}$ & $7,08 \pm 0,05^{\mathrm{a}}$ & $6,38 \pm 0,14^{\mathrm{b}}$ & $5,83 \pm 0,27^{\mathrm{c}}$ & $6,50 \pm 0,51$ \\
5 & $3,90 \pm 0,29^{\mathrm{de}}$ & $4,11 \pm 0,22^{\mathrm{de}}$ & $4,49 \pm 0,05^{\mathrm{cd}}$ & $4,19 \pm 0,09^{\mathrm{d}}$ & $4,17 \pm 0,27$ \\
10 & $3,47 \pm 0,06^{\mathrm{fg}}$ & $3,88 \pm 0,28^{\text {ef }}$ & $3,62 \pm 0,13^{\mathrm{f}}$ & $3,11 \pm 0,06^{\mathrm{g}}$ & $3,52 \pm 0,32$ \\
\hline 15 & $4,69 \pm 1,53$ & $5,02 \pm 1,55$ & $4,83 \pm 1,22$ & $4,38 \pm 1,20$ & \\
\hline Rataan & & &
\end{tabular}

Keterangan: Superskrip yang berbeda pada baris dan kolom yang sama menunjukkan perbedaan nyata $(\mathrm{P}<0,05) ; \mathrm{SD}=$ Simpangan baku

fermentasi berpengaruh secara nyata $(\mathrm{P}<0,05)$ terhadap kadar protein kasar silase kulit pisang kepok. Kadar protein kasar tertinggi diperoleh pada kombinasi perlakuan 5\% tapioka dan lama fermentasi 14 hari. Hal ini karena tapioka dapat memberikan energi bagi mikroorganisme, sehingga memungkinkan mikroorganisme tumbuh secara optimal dan menghasilkan enzim pemecah protein. Protein tubuh mikroorganisme menyebabkan peningkatan protein kasar substrat. Tapioka paling baik digunakan pada level 5\%, dan konsentrasi yang lebih tinggi mengakibatkan hilangnya protein kasar. Hal ini sejalan dengan temuan Utomo et al. (2013) yang menemukan bahwa peningkatan jumlah onggok dari 15\% menjadi 30\% menyebabkan penurunana kadar protein kasar silase tersebut.

Ketika kadar tapioka ditingkatkan maka kandungan protein kasar menurun. Tapioka merupakan bahan makanan berkarbohidrat tinggi yang menjadi sumber energi. Menurut Atika et al. (2015) bahwa semakin rendah kandungan protein kasar silase limbah sayuran akibat semakin bertambahnya penggunaan tepung tapioka. Penggunaan tepung gaplek 5, 10, dan 15\% menurunkan kadar protein kasar limbah sayuran masing-masing sebesar 10,3, 19,87 dan $23,64 \%$

Lama fermentasi mempengaruhi kadar protein kasar silase kulit pisang kepok. Lama fermentasi hingga 14 hari meningkatkan kandungan protein kasar, namun menurun pada lama fermentasi lebih dari 14 hari.
Hal ini disebabkan pola pertumbuhan mikroorganisme yang cepat pada awal inkubasi, kemudian melambat hingga mencapai pertumbuhan optimum. Menurut Irtwange and Achimbe (2009) bahwa pola pertumbuhan mikroorganisme berkorelasi positif dengan kadar protein kasar pada substrat yang terbentuk.

\section{Kadar Serat Kasar Silase Kulit Pisang}

Rata-rata kadar serat kasar pada penelitian ini sebesar 9,43\% (Tabel 3). Lebih rendah daripada kulit pisang yang difermentasi ragi tape yaitu 12,71-13,02\% (Koni et al., 2019). Penurunan kadar serat kasar $(\mathrm{P}<0,05)$ karena adanya interaksi aras tapioka dan waktu fermentasi. Perlakuan tapioka $15 \%$ dan waktu fermentasi 28 hari menghasilkan penurunan kadar serat kasar tertinggi. Peningkatan kadar tapioka memberikan sumbangan sumber energi bagi mikroorganisme, mengakibatkan peningkatan jumlah mikroorganisme sehingga jumlah enzim selulase yang dihasilkan pun makin tinggi. Jumlah serat kasar tereduksi tinggi maka yang tersisa pada substrat rendah. Menurut Wajizah et al. (2015) bahwa penurunan $6,61-9,64 \%$ serat kasar pada silase pelepah sawit yang menggunakan aditif. Temuan penelitian ini sesuai dengan temuan Atika et al. (2015) yang menyatakan bahwa peningkatan penggunaan tepung gaplek sebagai silase aditif telah mengakibatkan penurunan kadar serat kasar silase limbah sayuran.

Peningkatan level tapioka menurunkan 
Tabel 3. Kadar serat kasar(\%) silase kulit pisang yang difermentasi menggunakan aras tapioka dan waktu fermentasi yang berbeda

\begin{tabular}{cccccc}
\hline \multirow{2}{*}{$\begin{array}{c}\text { Level Tapioka } \\
(\%)\end{array}$} & 7 & 14 & 21 & 28 & \multirow{2}{*}{ Rataan \pm SD } \\
\cline { 2 - 5 } & $9,75 \pm 0,51^{\mathrm{c}}$ & $10,36 \pm 0,06^{\text {bc }}$ & $10,63 \pm 0,70^{\mathrm{b}}$ & $13,71 \pm 0,63^{\mathrm{a}}$ & $11,11 \pm 1,66$ \\
10 & $9,76 \pm 0,20^{\mathrm{c}}$ & $8,51 \pm 0,41^{\text {de }}$ & $10,01 \pm 0,57^{\mathrm{c}}$ & $7,81 \pm 0,86^{\mathrm{f}}$ & $9,03 \pm 1,06$ \\
15 & $8,81 \pm 0,43^{\mathrm{d}}$ & $8,48 \pm 1,83^{\text {de }}$ & $8,25 \pm 0,19^{\mathrm{e}}$ & $7,19 \pm 0,14^{\mathrm{g}}$ & $8,18 \pm 1,02$ \\
\hline Rataan & $9,43 \pm 0,59$ & $9,11 \pm 1,32$ & $9,62 \pm 1,16$ & $9,57 \pm 3,16$ & \\
\hline
\end{tabular}

Keterangan: Superskrip yang berbeda pada baris dan kolom yang sama menunjukkan perbedaan nyata $(\mathrm{P}<0,05) ; \mathrm{SD}=$ Simpangan baku

Tabel 4. Kadar lemak kasar (\%) silase kulit pisang yang difermentasi menggunakan aras tapioka dan waktu fermentasi yang berbeda

\begin{tabular}{cccccc}
\hline \multirow{2}{*}{$\begin{array}{c}\text { Level Tapioka } \\
(\%)\end{array}$} & 7 & 14 & 21 & 28 & Rataan \pm SD \\
\cline { 2 - 5 } & $10,33 \pm 0,39^{\text {cd }}$ & $11,07 \pm 0,16^{\text {b }}$ & $10,39 \pm 0,79^{\text {cd }}$ & $13,65 \pm 0,12^{\text {a }}$ & $11,35 \pm 1,46$ \\
\hline 5 & $9,76 \pm 0,59^{\text {de }}$ & $10,81 \pm 0,53^{\text {bc }}$ & $9,38 \pm 0,86^{\text {ef }}$ & $8,93 \pm 0,13^{\text {f }}$ & $9,71 \pm 0,88$ \\
10 & $10,06 \pm 0,28^{\text {d }}$ & $8,31 \pm 0,64^{\text {fg }}$ & $8,21 \pm 0,48^{\mathrm{g}}$ & $6,24 \pm 0,08^{\mathrm{h}}$ & $8,21 \pm 1,46$ \\
\hline 15 & $10,05 \pm 0,45$ & $10,06 \pm 1,39$ & $9,33 \pm 1,14$ & $9,60 \pm 3,25$ & \\
\hline Rataan & &
\end{tabular}

Keterangan: Superskrip yang berbeda pada baris dan kolom yang sama menunjukkan perbedaan nyata $(\mathrm{P}<0,05) ; \mathrm{SD}=$ Simpangan baku

kadar serat kasar kulit pisang. Turunnya kadar serat kasar ini disebabkan karena aktivitas mikroorganisme yang menghasilkan enzim selulase pada proses fermentasi. Silase menurut Despal et al. (2011) merupakan fermentasi spontan yang melibatkan bakteri asam laktat. Bakteri asam laktat menurut Yanuarianto et al. (2020) merupakan bakteri selulolitik yang dapat menghasilkan selulase yang dapat mencerna selulosa menjadi glukosa. Menurut Wajizah et al. (2015) bahwa penurunan serat kasar pada silase pelepah sawit yang menggunakan karbohidrat mudah larut 6,61-9,64\%. Menurut Riswandi (2014) bahwa kadar serat kasar silase eceng gondok terendah pada penggunaan $5 \%$ tepung ubi kayu..

\section{Kadar Lemak Kasar Silase Kulit Pisang}

Rataan kadar lemak kasar silase kulit pisang dalam penelitian ini 9,76\% (Tabel 4). Kadar lemak kasar ini lebih tinggi daripada lemak kasar kulit pisang yang dikeringkan yaitu lemak kasar 6,2\% (Wadhwa and Bakshi, 2013).

Kadar lemak kasar silase kulit pisang dipengaruhi secara nyata $(\mathrm{P}<0,05)$ pada kombinasi perlakuan level tapioka dan lama fermenatasi hingga 28 hari. Hal ini menunjukkan bahwa kandungan lemak kasar dipengaruhi oleh kedua faktor perlakuan (level tapioka dan lama fermentasi). Perlakuan lama fermentasi 14 hari dan kadar tapioka 5\% menghasilkan kadar lemak kasar tertinggi. Penggunaan aditif silase cenderung menurunkan kadar lemak, kemungkinan disebabkan oleh mikroorganisme menggunakan lemak sebagai sumber energi.

Kadar tapioka menurunkan kadar lemak kasar pada silase kulit pisang kepok. Hal ini karena kandungan lemak kasar tapioka yang rendah. Oboh and Elusiyan (2007) menyatakan bahwa tapioka memiliki kadar protein kasar 6,4\%, serat kasar 3,6\%, lemak kasar 2,9\% dan karbohidrat $85,5 \%$. Menurut 
Tabel 5. Kadar abu (\%) silase kulit pisang yang difermentasi menggunakan aras tapioka dan waktu fermentasi yang berbeda

\begin{tabular}{cccccc}
\hline \multirow{2}{*}{$\begin{array}{c}\text { Level Tapioka } \\
(\%)\end{array}$} & 7 & 14 & 21 & 28 & Rataan \pm SD \\
\cline { 2 - 5 } & $7,45 \pm 0,15^{\text {de }}$ & $6,58 \pm 0,09^{\mathrm{f}}$ & $6,89 \pm 0,26^{\mathrm{f}}$ & $5,55 \pm 0,48^{\mathrm{g}}$ & $6,62 \pm 0,76$ \\
\hline 5 & $8,06 \pm 0,10^{\mathrm{c}}$ & $7,69 \pm 0,18^{\text {cd }}$ & $7,72 \pm 0,49^{\text {cd }}$ & $7,07 \pm 0,17^{\text {ef }}$ & $7,63 \pm 0,44$ \\
10 & $10,66 \pm 0,43^{\mathrm{a}}$ & $10,77 \pm 0,36^{\mathrm{a}}$ & $10,03 \pm 0,06^{\mathrm{b}}$ & $10,15 \pm 0,2^{\mathrm{b}}$ & $10,40 \pm 0,42$ \\
\hline 15 & $8,72 \pm 1,49$ & $8,35 \pm 1,99$ & $8,21 \pm 1,43$ & $7,59 \pm 2,09$ & \\
\hline Rataanl & & &
\end{tabular}

Keterangan: Superskrip yang berbeda pada baris dan kolom yang sama menunjukkan perbedaan nyata $(\mathrm{P}<0,05) ; \mathrm{SD}=$ Simpangan baku

Utomo et al. (2016) bahwa kandungan lemak kasar bahan aditif silase dapat mempengaruhi kadar lemak silase yang dihasilkan. Lebih lanjut, dilaporkan bahwa jumlah onggok sebagai aditif silase meningkat maka kandungan lemak kasar pada silase isi rumen menurun. Temuan penelitian ini berbeda dengan Atika et al. (2015) yang menemukan bahwa peningkatan kadar tapioka pada silase limbah sayuran dapat meningkatkan kadar lemak kasar.

\section{Kadar Abu Silase Kulit Pisang}

Pada penelitian ini kadar abu rata-rata $8,22 \%$ (Tabel 5). Kadar abu ini lebih rendah dari kadar abu pada kulit pisang seperti yang dikemukakan Diarra, (2018) bahwa kadar abu pada kulit pisang berkisar 17,45\%.

Hasil analisis varians menunjukkan terdapat interaksi $(\mathrm{P}<0,05)$ antara level tapioka dan lama fermentasi terhadap kadar abu silase kulit pisang. Hal ini menunjukkan bahwa kadar abu kulit pisang dipengaruhi oleh lama fermentasi dan level tapioka. Berdasarkan uji DMRT terlihat bahwa perlakuan level tapioka $15 \%$ dengan lama waktu 14 hari menghasilkan kadar abu tertinggi yaitu 10,77\%. Level tapioka $15 \%$ meningkatkan kadar abu silase kuli pisang. Hal ini disebabkan karena penambahan kadar abu dari aditif yaitu tepung tapioka. Oboh, (2006) menyatakan bahwa tepung tapioka mengandung $1,9 \%$ abu. Peningkatan waktu fermentasi menyebabkan penurunan kadar abu kulit pisang kepok. Hal ini disebabkan karena kadar abu (sumber mineral) pada silase dimanfaatkan mikroorganisme untuk pertumbuhannya.

\section{KESIMPULAN}

Kandungan serat kasar yang tinggi pada kulit pisang menjadi faktor pembatas dalam penggunaannya. Kandungan nutrien silase kulit pisang dipengaruhi oleh jumlah tapioka yang digunakan dan lama fermentasi. Perlakuan kombinasi kadar tapioka $15 \%$ dan lama fermentasi 28 hari menghasilkan kadar serat kasar paling rendah. Jadi kombinasi perlakuan terbaik adalah level tapioka $15 \%$ dengan lama fermentasi yang optimum 28 hari.

\section{UCAPAN TERIMA KASIH}

Penelitian ini dibiayai dari PNBP Politeknik Pertanian Negeri Kupang, untuk itu penulis mengucapkan terima kasih.

\section{DAFTAR PUSTAKA}

AOAC (Association of Official Analytical Chemists). 2005. Official Methods of Analysis of the Association of Official Analytical Chemists. 18th ed. Association of Official Analytical Chemist, Washington, DC.

Astuti, T., M. N. Rofiq, dan Nurhaita. 2017. Evaluasi kandungan bahan kering, bahan organik dan protein kasar 
pelepah sawit fermentasi dengan penambahan sumber karbohidrat. J. Peternak. 14:42-47.

Atika, T., Liman, dan R. Sutrisna. 2015. Pengaruh penambahan tepung gaplek dengan tingkat berbeda terhadap kandungan nutrisi silase limbah sayuran. J. Ilm. Peternak. Terpadu. 3: 110-115.

Despal., I. G. Permana., S. N. Safarina, dan A. J. Tatra. 2011. Penggunaan berbagai sumber karbohidrat terlarut air untuk meningkatkan kualitas silase daun rami. Media Peternak. 34: 69-76.

Diarra, S. S. 2018. Peel meals as feed ingredients in poultry diets: Chemical composition, dietary recommendations and prospects. J. Anim. Physiol. Anim. Nutr. (Berl). 102: 1284-1295.

Fitroh, B. A., W. Wihandoyo, and S. Supadmo. 2018. The use 3 of banana peel meal (Musa paradisiaca) as substitution of corn in the diets on performance and carcass production of hybrid ducks. Bul. Peternak. 42: 222-231.

Gasperz, V. 2006. Teknik analisa dalam penelitian percobaan. Edisi III. Tarsito, Bandung.

Irtwange, S.V and Achimbe O. 2009. Effect of The Duration of Fermentation on The quality of Gari. Journal of Biological Sciences. 1(3). 150-154.

Koni, T. N. I. 2013. Pengaruh pemanfaatan kulit pisang yang difermentasi terhadap karkas broiler. J. Ilmu Ternak dan Vet. 18: $153-157$.

Koni, T. N. I., J. Bale-Therik, and P. R. Kale. 2013. Utilizing of fermented banana peels by rhyzopus oligosporus in ration on growth of broiler. J. Vet. 14: 365370 .

Koni, T. N. I. dan T. A. Y. Foenay. 2019. Nilai Nutrien Dan Anti Nutrien Silase Kulit Pisang. Politeknik Pertanian Negeri Kupang, Kupang NTT.

Koni, T. N. I., T. A. Y. Foenay, and Asrul.
2019. The nutrient value of banana peel fermented by tape yeast as poultry feedstuff. J. Ilmu-Ilmu Peternak. 29: 211-217.

Mendoza, N. S., M. Arai, T. Kawaguchi, F. S. Cubol, E. G. Panerio, T. Yoshida, and L. . Johson. 1994. Isolation of mannan utilizing bacteria and the culture condition for mannanase production. World J. Microbiol. Biotechnol. 10: 51-54.

Oboh, G. 2006. Nutrient enrichment of cassava peels using a mixed culture of Saccharomyces cerevisae and Lactobacillus spp solid media fermentation techniques. Electron. J. Biotechnol. 9: 46-49.

Oboh, G. and C. A. Elusiyan. 2007. Changes in the nutrient and anti-nutrient content of micro-fungi fermented cassava flour produced from low- and mediumcyanide variety of cassava tubers. African J. Biotechnol. 6: 2150-2157.

Olagunju, A. I. and B. Ifesan. 2013. Changes in nutrient and antinutritional contents of sesame seeds during fermentation. J. Microbiol. Biotechnol. Food Sci. 2: 2407-2410.

Riswandi. 2014. Kualitas silase eceng gondok (Eichhornia crassipes) dengan penambahan dedak halus dan ubi kayu. J. Peternak. Sriwij. 3: 1-6.

Santi, R. K., D. Fatmasari., S. D. Widyawati, dan W. P. S. Suprayogi. 2012. Kualitas dan nilai kecernaan in vitro silase batang pisang (Musa paradisiaca) dengan penambahan beberapa akselerator. Trop. Anim. Husb. 1: 15-23.

Situmorang, N. A. R., B. Sukamto, dan E. Suprijatna. 2020. Pemanfaatan Protein pada Ayam Broiler yang Diberi Ransum Mengandung Kulit Pisang Fermentasi. Compos. J. Ilmu Pertan. 2:30-35.

Utomo, R., S. P. S. Budhi, dan I. F. Astuti. 2013. Pengaruh level onggok sebagai aditif terhadap kualitas silase isi rumen sapi. Bul. Peternak. 37: 173-180.

Level Tapioka dan Lama ... (Koni et al.) 
Utomo, R., C. T. Noviandi., A. Astuti., N. Umami., L. J. M. C. Kale-Lado., A. B. Pratama., N. A. Jamiil, dan N. Sugiyanto. 2016. Pengaruh penggunaan aditif pada kualitas silase hijauan Sorghum vulgare. In: Simposium Nasional Penelitian dan Pengembangan Peternakan Tropik. Fakultas Peternakan Universitas Gadjah Mada, Yogyakarta. p. 63-69.

Wadhwa and P. S. Bakshi. 2013. Utilization of fruit and vegetable wastes as livestock feed and as substrates for generation of other value added products. Available from: www.fao.org/

Wadhwa, M., M. Bakshi, and H. Makkar. 2015. Waste to worth : fruit wastes and by-products as animal feed. CAB Rev. 10: $1-10$.

Wajizah, S., S. Samadi., Y. Usman, dan E.
Mariana. 2015. Evaluasi nilai nutrisi dan kecernaan in vitro pelepah kelapa sawit (oil palm fronds) yang difermentasi menggunakan aspergillus niger dengan penambahan sumber karbohidrat yang berbeda. J. Agripet. 15: 13-19.

Widjastuti, T. and E. Hernawan. 2012.Utilizing of banana peel (Musa sapientum) in the ration and its influence on final body weight, percentage of carcass and abdominal fat on broiler. Lucr. Ştiinţifice - Ser. Zooteh. 57: 104-109.

Yanuarianto, O., M. Amin., S. D. Hasan., S. H. Dilaga, dan Subudy. 2020. Komposisi nutrisi dan kecernaan silase jerami jagung yang ditambah lamtoro dan molases yang difermentasi pada waktu berbeda. J. Ilmu dan Teknol. Peternak. Indones. 5: 70-77. 